\title{
There is no Cure for the Cancer of Stupidity
}

\author{
Rahul Hajare* \\ Department of Health Research, Ministry of Health and Family Welfare, India
}

Submission: December 01, 2017: Published: January 17, 2018

*Corresponding author: Rahul Hajare, Department Indian Council of Medical Research, Department of Health Research, Ministry of Health and Family Welfare, New Delhi, India; Tel: 011-26588590, Email: vantat@gmail.com

\section{Abstract}

The best definition for cancer is the statistic one in six - a reminder that beyond a point, one cannot control or ever completely prepare for the future. Believes cancer afflicts those who have a sinful past, people cannot compensate for the sin against the unseen. But when you see the background, it will be found it was divine justice, nothing else. Lung cancer means no accreditation. Unscientific opinion that illness is only too human to fall back on fantasy, or religion, when there are no rational explanation for random misfortunes.

\section{Short Commentary}

On the basis of criteria of assessment allotted for NBA work, the total effect has been carried out, which has shown that $9 \%$ staffs were moderately improved $(17.65 \%)$ and $40 \%$ staff $(78.43 \%)$ were mildly improved, while none of the staffs were completely improved. The trial was conducted to evaluate the efficacy of work flow as compared to replacement therapy in the management, along with the assessment of different initiative. The subjects were randomly divided into three groups. A total 18 staffs were selected for the study, out of which 13 staffs completed the study. Specialized biosafety rating scales like orientation as well as information technology rating scale, were adopted to assess the effect of therapy. The quality of work depends upon the quality of thought has been accepted [1]. NBA work cannot be evaluated in terms of file and paper work because investments of biosafety make a profit of privately managed low level transportation facility pharmacy institution make them different.

Individuals have the power to prevent the occurrence of these diseases by managing their health care and developing healthier food and lifestyle behaviours. How can they be motivated to do so, without providing them with a basic understanding about the important role the liver, the organ under attack, plays in maintaining their health and life itself? This is non-complaining complex organ and its miraculous hard working liver cells convert everything they eat breath and absorb through their skin into hundreds of life sustaining body functions 24/7 [2]. A positive result does not necessarily mean that the person has body support, as there are certain conditions that may lead to a false positive result for example lyme disease, bacterial leaching, lupus. The test may also be positive in such people to who carry the paternal negativity but who themselves are not infected with liver disorder.

Similarly staffs receiving liver therapy may have positive test. While showing a positive we general regarded as conclusive for a body life under attack, a negative test does not necessarily rule out. They need to understand how their food and life style choices can lead to reparable NBA accreditation privately managed in remote areas pharmaceutical Instituions. Unless we motivate individuals to protect this remarkable that is under attack by educating junior staff in school, these chronic illness will continue to impact the health and wellbeing of millions, shorten their lives while dramatically increase the burden on our healthcare system. Drug use, obesity, diabetes and atherosclerosis depend on each individuals making informed and healthier selection of food and drinks that protect their miraculous sustaining liver [3]. It is uncommon for negativity to develop after this time. During the early session, positive testing can be undertaken to exclude NBA. In staffs that are near to positive, the level of negative load is used as markers of the like senior staff and principal of progression to ignored.

The risk of lies the problem and the need for treatment and its success. Tragically, primary prevention that includes blaming technology is being ignored... lives will continue to be lost that could have been prevented and qualified cost will increase exponentially. Primary prevention is the key to saving lives and aware of the serious consequences related to teaching plan for laboratory work. The NBA accreditation is a 909090 formula organization dedicated to promoting healthy food and lifestyle behaviours and prevention of liver related disease through multifaceted liver health education programs [4]. The mission 
of NBA accreditation initiative is to make education a priority on national agenda. Promoting an education about the NBA to employer individuals to make informed can improve compliance and treatment outcomes for NBA and reduce the incidences of preventable NBA related thought including obesity, fatty liver, early onset diabetes, high cholesterol and cardiovascular disease. Primary prevention of NBA is the key to saving paper and application of green chemistry additional benefited with zero Carbon Dioxide (CO2) emission in college area.

\section{Results}

A total 18 staffs were selected for the study, out of which 13 staffs completed the study. Specialized rating scales like biosafety as well as the orientation rating scale, depression rating scale, and health condition senior staffs rating scale were adopted to assess the effect of therapy for accreditation.

The selected staffs were randomly separated into three groups as follows:

a) Group A: was treated with conjugated staff seen work flow once daily for 45 days.

b) Group B: was treated with small conjugated staffs seen work flow but ignored once daily for duration of 45 days.

c) Group C: was treated with separately work staffs seen and engaged in their assigned work for 45 days (After 7 days of continuous behavioral objective, a gap of 3 days in between before the next 7 days sitting with 3-3 day's gap after every 7 days). The staffs tended to be lady staffs in middle adulthood regular health. About $80 \%$ mentioned irregular habits, and about $60 \%$ were unidentified [5].

A little over half of the staffs (54.17\%) were of none of long relation of objective of NBA implementation and $22.92 \%$ were of fear with mind. Results of the study based off the conjugated staffs rating scale showed that Group C showed greater relief than the other two groups in flashes $(66.66 \%)$, sleep problems (80.39\%), in depressive mood (72.5\%), in irritability (69.81\%), and in anxiety (70.90\%). However, Group B showed significant improvement with flashes (62.22\%), sleep problems $(57.14 \%)$, depressive mood (66.66\%), irritability (55.31\%) and anxiety (50.94\%). Both groups B and C showed a lower benefit in symptoms compared with Group A, which was treated with conjugated staffs but quite unidentified crisis among them.

\section{Discussion}

Due to the difficulty in finding NBA studies that are large and focus on the topic of staff's health; the classical conclusions drawn from this literary analysis may seem unsubstantial. It is also worth noting that research that focuses on alternatives to biosafety medicine lump international policy together with classical or other accreditation, creating an unclear treatment plan that would never be prescribed by through principal practitioner. Due to these limitations in research it is not clear to what degree biosafety treatment may benefit NBA accreditation in sub kind transportation facility remote pharmacy institution, although the smaller studies used in this literary analysis show a definite success rate that supersedes the benefits of biosafety treatment thereby delaying the aging process of staffs in private pharmacy Instituions.

\section{Recommendation}

Based on the findings of our study, the following recommendations are suggested:

a) Increased educational programs to improve the level of awareness of healthy food.

b) University and educational inspectors especially accreditation may benefit from considering health in the context of improving their university's attendance rates and academic performance.

c) Transportation facility in reseanable cost.

d) Create a space for theory class of biosafety training in time table to reduce the hesitation of health related problem.

e) Yoga session class twice a month with yoga instructor beneficial to reduce depression sign.

f) Appointment of gynaecologist on chb.

g) Diet awareness workshop in dysmenorrhea once in a semester.

h) Diet awareness workshop in management of menopause once in a semester.

\section{Limitation}

This study was a cross-sectional study; hence, it precludes inferences of causality among such variables. Furthermore, the nature of self-reporting may have impacted the under-reporting of the conditions.

\section{Acknowledgment}

This study has been guided under the unparallel supervision and guidance of Hon'ble Dr. Ramesh Paranjape, Retired as Director \& Scientist 'G' National AIDS Research Institute, India. I express my sincere gratitude towards Sir for motivation and being great knowledge source for this work. I seek continuous support for my research career.

\section{References}

1. Hajare R 2017 Process from Biosafety Working Style to Accreditation Trends Driving Self-financed Private Pharmacy Institution in Remote Areas Individuals in India. J Tradit Med Clin Natur 6: 230.

2. Rahul H 2017 Early Rising May Be Linked to Mental Health Issues in Institute of Pharmaceutical Science an Observational Study Draws Inference from a Legal to Cultural Principles through Independent Variables. Biomed J Sci \& Tech Res 1(1).

3. Rahul H 2017 Understanding Academic and Educational Problems Fit for Purpose in the Contributing to Attentional and Learning Difficulties in Our Children?. Glob J Otolaryngol 11(5): 555822. 
4. Rahul H 2017 The Impact of Relocation and Transfer of naive B.Pharm Students to Adjacent Class room in Privately Managed Self finance Co-Educational Pharmaceutical Institute and Survey Investigation of Attitude towards Pharmaceutical Syllabus. Biomed J Sci \& Tech Res. 1(1).
5. Hajare R 2009 Nutritional attributes of edible mushrooms. Antiseptic 106(1): 20-22.

\section{Your next submission with Juniper Publishers} will reach you the below assets

- Quality Editorial service

- Swift Peer Review

- Reprints availability

- E-prints Service

- Manuscript Podcast for convenient understanding

- Global attainment for your research

- Manuscript accessibility in different formats

( Pdf, E-pub, Full Text, Audio)

- Unceasing customer service

Track the below URL for one-step submission https://juniperpublishers.com/online-submission.php 